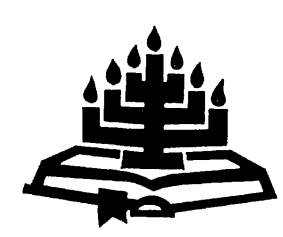

\title{
Hijab and the construction of female religious identity
}

\author{
Georgina L. Jardim \\ School of Biblical Studies and Bible Languages \\ Potchefstroom University for CHE \\ POTCHEFSTROOM \\ E-mail: sktglj@puknet.puk.ac.za \\ J.M. (Koos) Vorster \\ School of Ecclesiastical Sciences \\ Potchefstroom University for CHE \\ POTCHEFSTROOM \\ E-mail: skwjmv@puknet.puk.ac.za
}

\begin{abstract}
Hijab and the construction of female religious identity

Thinking of Muslim women, the first image that usually comes to mind is a veiled woman or, especially after 11 September 2001, the burqa (Afghan name and form of veiling) in Afghanistan. This image of prescriptive veiling is immediately viewed as oppressive and as an indication of the inferior status of women in Islam.
\end{abstract}

In this article an attempt is made to present the different ways in which hijab (Islamic practice of veiling) is interpreted and applied, followed by an analysis of Islamic identity as reflected in Islamic scripts. Personal identity is discussed according to Jensen's distinction that sheds some light on the different spheres of human reality within Islam, that is: the social person, the legal person and the religious person.

This article aims to present orthodox and feminist views on personal identity that should be informative of the orientation of Muslims within society at large.

Opsomming

Hidjab en die konstruksie van vroulike religieuse identiteit

Wanneer ons dink aan die Moslemvrou is die algemene beeld gewoonlik dié van 'n gesluierde vrou of, veral na 11 September 2001, die boerqa (Afghaanse naam en vorm van die sluier) in 
Afghanistan. Hierdie beeld van verpligte versluiering word beskou as onderdrukkend en as 'n aanduiding van die mindere status van vroue in Islam.

In hierdie artikel word gepoog om die verskillende maniere waarop hidjab (Islamitiese praktyk van versluiering) geïnterpreteer en toegepas word, weer te gee. Hierna volg 'n analise van Islamitiese identiteit soos dit na vore kom in verskillende Islamitiese geskrifte. Persoonlike identiteit word beskryf aan die hand van Jensen se onderskeid tussen drie tipes persoon. Hierdie verdeling werp lig op verskillende aspekte van menslike bestaan soos gesien vanuit die raamwerk van die Islam: die sosiale persoon, die regspersoon en die godsdienstige persoon.

Hierdie artikel bied ook ortodokse en feministiese sienings oor persoonlike identiteit wat die Moslem se oriëntering in die breëre samelewing duideliker behoort te maak.

\section{The identity of clothing}

According to Den Heyer and Schelling's Symbolen in de bijbel (2000), clothing functions not only as protection against cold and heat or as a means of beautification, but has an overall social function: "Kleding schept duidelijkheid over wie wat is en waartoe behoort. Daardoor draagt zij bij aan intermenselijke communicatie" (Den Heyer \& Schelling, 2000:586). It is against this background that the prohibition in Deuteronomy 22:5 must be seen, where women and men are warned against wearing one another's clothes. Further Den Heyer and Schelling (2000: 233) propose that people derive their identity from their clothing or conversely, that clothing mirrors the identity. Veiling also plays a role in the Old Testament (Song of Songs 4:1), although the extent of veiling is unclear. We can, however, ask ourselves what the symbolic content of veiling implies for the modern-day Western and/or Christian bride.

Clothing can therefore be understood as an expression of the way in which one understands oneself to be. Clothing relates the person as an individual in or as part of a communal setting expressing the acceptance or denial of propositional values of the community one belongs to.

\subsection{Hijab: Origins and application}

The most obvious identification of the Muslim woman (muslima) is certainly the covering of the head and often the whole body with a veil. The first and foremost meaning of the concept hijab is literally a veil or partition. Aside from its literal sense, in metaphysics al-hijab refers to the veil that separates humankind, or the world, from God. Glassé (1989: 156) gives the use of this term as applied today, as the common 
secondary meaning. According to Mohammed al-Buti (in Rafiqul-haqq \& Newton, 1996:2) "Muslim teachers unanimously agreed in every generation that a female should cover all her body, except her hands and face, that is without any make-up, from strangers." Malikiyah and Hanafiyah legal systems make this further distinction: "If the woman's face is naturally beautiful, then she must cover her face for fear of being a temptation to men" (Rafiqul-haqq \& Newton, 1996:4). Most sources indicate that the use of hijab is derived from the Qur'an, Sura 33:59:

O Prophet, tell your wives and daughters and the believing women to draw their outer garments around them (when they go out or are among men). That is better in order that they may be known (to be Muslims) and not annoyed/molested ...

The application and the extent of covering vary from community to community:

Today, reasons for veiling are as varied as the types of covering women wear, from the long robes and colourful scarves in the North African countries to the black-on-black garb of the conservative Gulf states (Prusher, 2000: par. 13).

The purpose on the whole is modesty for both men and women. Mary 'Ali (2001) argues that this results in both sexes being evaluated on grounds of intelligence and skills, rather than appearance and sexuality. She is further of the opinion that a Muslim woman who covers her head makes a statement as to her identity and is therefore regarded as modest and of high character. She purports that hijab does not only constitute the covering of the body, but general behaviour: "Hijab is not merely covering dress but more importantly, it is behaviour, manners, speech and appearance in public. Dress is only one facet of the total being" ('Ali, 2001: par. 22). In this article hijab is, therefore, taken as a symbolic application presenting an understanding of the general status and rights of women in Islam.

\subsection{Hijab: Praxis and interpretation}

The interpretation of the injunction on clothing reveals divergence, as the following examples will show. In Iran during the 1970s the wearing of the chador was a symbolic form of resistance to the pro-Western stance of the then Shah. This is undergoing change once again, apparent from the article "Jeans and mascara under the veil" (Hilsum, 1998: par. 7):

The outer signs of change are small but significant, and women are in the forefront. They must still be cloaked from head to toe in hijab ... which has come to symbolise to the world Islamic orthodoxy. But the once-dreaded neighbourhood komiteh thugs who used to beat 
women in the street for 'bad hijab' have lost their zeal. In Tehran, young women are pushing their headscarves back to reveal a little more hair. Wearing make-up has become a feminist statement.

Shira Boss (1998) reveals another facet of the issue in Turkey, where the headcovering is part of a fashion trend being exported to more conservative Muslim countries like Saudi Arabia. On the other side (of the Atlantic we might add) the reverse seems to be applicable. Reports from Canada, France and America tell of women prepared to face persecution for wearing hijab, now prohibited by secular legal injunctions. The issue has led to an ironical solidarity from non-Muslims in the Veiled Solidarity Movement where "non-Muslim women and girls in church groups, high schools, college campuses, and community organisations across the country are donning black veils, tied around their necks like hijabs" (Shah, 2002). The Solidarity Movement is one of the reactions of the attacks of 11 September 2001 in the USA, which is a driving force in current discourse on hijab. Change of meaning and application is evident and it is clearly a response to a variety of catalytic forces as llene Prusher (2000: par. 11) points out:

The 20th century often saw the veil hijacked for political purposes. Nationalists from Turkey's Ataturk to Egypt's Gamal Abdel Nasser wanted the hijab to come off. Fundamentalists in Egypt's Muslim Brotherhood, Lebanon's Hizbullah, and the Palestinian Hamas wanted it back on. Leaders who went overboard in their pro-Western orientation found themselves facing a backlash.

Out of these reports it is evident that women in or out of hijab are appropriated by opposing socio-political forces as a symbolic representation of ideology. This situation does not necessarily imply that hijab is proscribed for women by ideologues. The examples also point out that women appropriate the institution of hijab for themselves. The essence of this article is thus concerned with the use of hijab as a definition of female persons.

\subsection{Hijab in a changing context}

The diversity in the application of Muslim dress code highlights the different socio-political forces that are impacting on and emanating from the Islamic community. These forces are not always issues of faith, neither are they necessarily propagated by the religious leadership. Hijab is not even always related to an affirmation or negation of womanhood. What is the impetus behind this conceptual presentation of Muslim women? 
Eric Lott (1988:32) argues that change, even in a rigorous religious tradition, is historically inevitable and that the process of change cannot always be steered by the clergy:

We may question ... whether even the most militantly conservative Imam can prevent people's perception of things from undergoing change. For in any religious tradition, the same form of prayer or of ritual as that performed for generations may well have, to greater or lesser extent, different meaning for each generation ... The historical process ... is necessarily a hermeneutical process, and the different ways in which people interpret their history, i.e. their subjective impact on it, itself has consequences for that history's development.

The question of change is thus not a uniquely Islamic one; it rather seems to be an issue of religious expression in a secularising, globalising society. Daniel Brown (1996:1) is of opinion that the Muslim struggle with coming to terms with modernity and how identity is to be reflected is related to that of Christian and other religious communities. The issues presented by the modernising process present us with varying interpretations and expressions. The variances in interpretation lead to questions such as: How does the conceptual formulation of the female person inform us about the notions or core vision of Islam? In other words, how does the conceptualising of female identity function as a meaning communicator to the adherents of the Islamic faith and to nonadherents?

The challenge in the determination of Islamic identity lies firstly, to not only define it in terms of Western concepts, but also to find the implicit meaning of person in non-Western, Islamic societies, secondly to find similarities and differences to the Western concept of person, and thirdly to interpret it accordingly (Kippenberg et al., 1990:2). Integral to the understanding of the Islamic response to these pressures is that all logic and metaphysics need to be reconciled with the Prophet's revelation (Keddie, 1968:46). Therefore Islam does not make the distinction between religion and politics, or religion and science1:

1 C. du P. le Roux (1986:33) discusses problems with scientific investigation or interpretation of the Qur'anic text for Muslim and non-Muslim scholar alike in a series under the title Koran en Metodologie (Qur'an and Methodology). He points out various issues relevant to the scientific study of Islam, specifically the textcritical approach, and concludes that a struggle of methods has ensued. These issues are currently a bone of contention among Occidental and Muslim scholars, as illustrated in the article by Alexander Stille (2002:1-5) "Radical new views of Islam and the origins of the Koran". He quotes Puin as stating that there is a need for a "critical edition' of the Koran ... one based on recent philological work", but, he says, "the word critical is misunderstood in the Islamic world - it is seen as criticizing or attacking the text"' (Stille, 2002:4). 
Islam has always stood for a rejection of the secular, understood as a category of something exempted from the divine rule. It has boldly claimed to include all things under God. It does not separate the religious and the political ... In the restrictive sense there is nothing religious and nothing secular. All are muslim, tributary to God. The only distinction that applies is between islam ${ }^{2}$ and non-islam (Cragg, 1973:189).

Female identity can only be deduced within an understanding of this general Islamic identity and conversely should inform about Islamic selfunderstanding. The Gröningen Working Group for the Study of Religious Symbols constructed the following general assumption for the identity of person, which is the point of departure for this article:

Every individual obtains self-awareness only by being an object to others: the individual both internalises the attitudes of other people towards him/her ${ }^{3}$ as social relations and presents her/himself to others through means provided by the culture to which $\mathrm{s} / \mathrm{he}$ belongs. This distinction between social role and the culturally determined symbolic presentation of the self, is an important starting point for research on the concept of person (Kippenberg et al., 1990:3).

This article attempts to present different Islamic views on the current role and status (conceptualising) of women in Islam and hopes that the phenomenological discussion thereof will lead to a better understanding of the role and status of women in religions. The conceptualising of the person should inform us about ideas inherent to a religious tradition as an ideological system and about the categories that are employed to determine the person as an agent of action and motivation (Jensen, 1989:178).

\section{Symbolic presentation and personal identity in Islam}

The whole realm of symbolism in Islam was greatly influenced by the purifying process it inspired in its formative period. 4 An extreme example of the iconoclastic nature of Islam is the destruction of the Bamiyyan Buddhas by the Taliban in Afghanistan in 2000/01. Cragg (1973:160)

2 "islam": an Arabic noun form - not meant as the name of the religion Islam.

3 Insertion of third person feminine pronoun my own as this definition is applied to female persons in this article.

$4 \quad$ Leo III the Isaurian (the Syrian) (c. 675-741) probably instigated the iconoclastic period in Byzantium under the influence of Muslims and/or Jews. 
regards this to be a result of the break with the jahaliyya ${ }^{5}$ era, whence the eradication of idolatry and other practices had to be rooted out for the establishment of Islamic mores: "In this radical destruction of the idols, however, there was an unintended sacrifice or rejection of the whole realm of symbol ..."

Eric Lott (1988:35) means it is due to the perceived "remoteness" of God. This entails a severe penalty on blasphemy or trying to convey the Creator or His creation through artistic form. The question arises how the Muslim gives expression to the inherent need for the symbolic as Lott (1988:11) expounds that religiosity and the conceptualisation process has become irrevocably connected to each other.

Conceptualisation of the person is the visible expression of notions about the character or nature of that person. According to Jensen (1989:190) Islam does not focus so much on the nature of man, ${ }^{6}$ in contrast to other major world religions: "... it [man's nature] seems rather to be taken for granted and then elaborated on". It follows that more comprehensive Islamic concepts of the person must be deduced from descriptions of, for instance, behaviour, values, gender relations and so on. Hijab being the symbolic representation of female identity, the question is thus: What does it mean to be a muslima (Muslim woman)?

The Islamic religion (din) contains prescriptions illustrating human obligation to Allah. These rules "define man as a servant ('abd) in relation to Allah as the Lord (rabb) and are designed to keep man conscious of this" (Jensen, 1989:192). Daily prayers, food prescriptions, fasting and other prescriptions keep the Muslim constantly aware of the divine purpose of life and by fulfilling these obligations and prescriptions he/she qualifies as a true human being (Jensen, 1989:193). The correct assessment of identity and its duties are crucial to the Muslim's successful achievement of a life of faith. The sources of Islamic injunction are the Qur'an and sunnah (guidance) of the Prophet, as incorporated in the hadith (tradition literature). These prescriptions are

5 jahaliyya = from jahil, "ignorant", "untaught". The time of ignorance" or period of Arab paganism preceding the revelation of Islam (Glasse, 1989:204).

6 Man: (as used throughout) a human being, or the human creature regarded abstractly and without regard to gender, hence, the human race or humanity (Stumpf, 1983:G-3). On the term "man" and the equivalent term "human being" Praetorius argues that it is ambiguous as an apparently "gender-neutral" concept, but that it is often employed to hide androcentric ideas: "The man is abstracted into an apparently universal sexless individual, in which women can be included or not, according to their interest in the statement. The world is construed as a kind of pyramid whose point is occupied by the man who has been universalized into the 'human being"' (Praetorius, 1998:81). I therefore choose the term "humankind" in most instances. 
interpreted through ijtihad (authoritative research) and systematised in shari'ah.

The coherence between thought and praxis will be evaluated in this article from the viewpoint of some representatives of male orthodoxy, female orthodoxy and Islamic feminists as reflected in academic and non-academic sources. These views are presented within the framework provided by Jensen (1989:191) in his analytic division between three "kinds" of person in Islam: the social, the legal and the religious person. Although these aspects are interrelated and form part of a paradigmatic whole, the categories are employed to facilitate discussion of the sources and functions of the social, legal and religious aspects of Islamic life.

\subsection{The social person}

Islam as doctrine is not always of explicit importance in the daily life of the believer. It may be referred to in order to explain a certain practice, since it contains prescriptions that can serve as a basis for interpretations of every aspect of life (Jensen, 1989:191). The emphasis, however, is on the community (ummah) (Doi, 1984:423):

... individual freedom is sacred within the ethical limits imposed by the shari'ah, and it will be considered sacred only as long as it does not conflict with the larger social interest or as long as the individual does not transgress the rights of others.

Lois Lamya' al-Faruqi (2001:2) explains this principle in terms of "individualism" against "the greater organisation":

Islam and Muslim women generally advocate moulding of individual goals and interests to accord with the welfare of the larger group and its members. Instead of holding the goals of the individual supreme, Islam instils in the adherent a sense of his or her place within the family and of a responsibility to that group.

She interprets this subordination of interests to the larger group not as oppression, but maintains that Muslim women regard their goals as necessitating balance with, or even subordination to the interests of the family group (Al-Faruqi, 2001:2). Women's social needs and customary usages are structured within the religion, and traditions are generated and validated through it. Merryl Davies (1988:64) sees this as the role of Islamic religion (din). However, the welfare of the community is of paramount importance or as explained by Jensen (1989:194) "... the regulations of social life [have] ... the well-being of the group as the major concern, because it is only then that the individual can fulfill his religious, moral and social obligations". 
Al-Faruqi (2001:3) infers that the Islamic environment specifies differentiation between male and female roles and responsibilities in society, in contrast to the Western feministic movement which has put the emphasis on the roles of providing financial support, of success in career and of decision-making, "while those dealing with domestic matters, with child care, with aesthetic and psychological refreshment, with social interrelationships, were devalued and even despised". Imam Ibrahim Bam (2001) ratified this view in a radio interview on Islam:

Women have the right to work, but the obligation to provide financially is upon the male; the father if she still stays at home or her husband if she is married. If she has special skills that could benefit the community, she must be allowed to make this contribution. The highest role of a woman, however, is as a mother.

Al-Faruqi (2001:3) argues that both types of roles are equally deserving of pursuit and respect and that when accompanied by the equity demanded by this religion, a division of labour along gender lines is generally beneficial to all members of society. The ideal defining roles of female and male are in accordance with her/his biological merits. Doi (1984:117) perceives the limiting of female participation in society as Islamic injunction that must be viewed within the relational aspect of society and as a choice the woman makes for Islam: "Once the woman gets married, she accepts the Islamic ruling on the functioning of the family".

Nayyar Javed (1994) pits these arguments as orthodox discourse that places women into an ideological framework. She (Javed, 1994: par. 1) is of the opinion that this discourse restricts women to the role of service providers: "In gender-based transactions women are required to provide sexual, emotional and physical services to men in order to get protection."

Orthodox Islam thus provides a relational paradigm with which not all Muslims agree. The paradigmatic construction is based on biological difference and has implications for the legal status of women.

\subsection{The legal person}

The role of fiqh (Islamic jurisprudence) in the Muslim experience is not limited to legal matters; it is rather a daily reality through the application of shari'ah which makes an overlap between the discussion of the three types of person unavoidable, as the shari'ah is the legal system derived 
from the Qur'an, regulating all social matters. ${ }^{7}$ The aim of shari'ah is to "regulate the relationship of humankind with Allah and humans with each other within a worldview of unity (tawhid). This is the reason why the shari'ah law cannot be separated from Islamic ethics" (Doi, 1984:7). Concerning the status of men and women under shari'ah, I will briefly mention a few aspects as illustrative of Muslim opinion; the purpose being to present Muslim views on the functioning of gender roles in Islamic society and not as an overview of the origin or specifics of shari'ah.

Al-Faruqi (2001:4) interprets the law to mean that men and women have separate legal status that allows women to negotiate contracts, run a business and own or earn property independently. Marriage makes no difference to a woman's legal status, property or earnings, or even her name. If she commits a civil offence, her penalty is no less or no more than a man's in a similar case according to Sura 5:83; $24: 2$. She is also entitled to the same compensation as a man when wronged (Sura 4:9293). Once again the criteria rest on the welfare of the community.

Regarding laws of inheritance, the woman is entitled to half the share of a man: "To the male a portion equal to that of two females" (Sura 4:11). However, shari'ah surprisingly entitles the freed slave (mistress) of a deceased to inheritance (Doi, 1984:277). These distinctions are explained as part of the particular roles of males and females in society and their responsibilities towards society as explained under the section "social person". Yusuf 'Ali (1975: footnote no. 255, p. 90) comments as follows on Sura 2:228:

The difference in economic position between the sexes makes the man's rights and liabilities a little greater than the woman's. Q iv.34 refers to the duty of the man to maintain the woman, and to a certain difference in nature between the sexes. Subject to this, the sexes are on terms of equality in law, and in certain matters the weaker sex is entitled to special protection.

Distinction in legal rights is viewed against the background of the greater whole, wherein the economic function of men and women differ to make provision for the biological differences between man and woman. The socio-legal responsibilities are therefore a compensation for the special skills of women and men and the unequal division in inheritance must be viewed in this light (see Doi, 1984:271-346).

7 Jensen (1989:192) maintains that figh "is based on uncompromising individualism and it does not accept any social unit beyond the family (except ummah)". This seems to be rather a contradiction in terms as the "social unit, ummah" equals Islamic society at large as a collective term and cannot, in my view, be equated with "individualism". 
It is but one part of a comprehensive system in which women carry no legal responsibility to support other members of the family, but in which men are bound by law as well as custom to provide for all their female relatives (Al-Faruqi, 2001:4).

Javed (1994: par. 11) takes exception to these statements and regard them as a manipulation of women's religious sentiments by instilling a sense of gratitude in women for being elevated in status by "(1) stopping female infanticide practised by jahiliyya (pre-Islamic Arab society); (2) inheritance right (less than what men inherit), and (3) other rights that are mostly related to financial and social protection in case of marriage breakdown". She (1994:4) attributes this to the exclusion of women by the orthodoxy in the history of knowledge production and describes the motive as a political agenda "that serves males of the privileged class".

The social and legal rank of women in religious traditions ultimately derives from the explication of their holy text; the ultimate reference being the reason for human Creation.

\subsection{The religious person}

This section does not claim to give a full analysis of the Islamic scriptural distinction between male and female. It presents a thematic analysis explicating the scripturalist referent of gender arrangements in Islam.

The distinction between the status of men and women is sanctioned by the Qur'an (Sura 2:228, 4:34) although the Qur'an specifies that the creation of male and female persons are according to God's will: "To God belongs the dominion of the heavens and the earth. He creates what He wills. He bestows male or female according to His Will" (Sura 42:49). The creation of humankind is depicted consistently with this view. Qur'anic humanity is a unitary creation and there is no reference in the Qur'an to a secondary creation of women (or Eve) and neither is the woman named. The unitary creation of mankind is described as being from one person (nafs) ${ }^{8}$ (Sura 4:1).

A further comparison with biblical concepts shows that the Qur'an does not blame woman for the Fall. On the contrary, the Qur'an depicts Adam and his partner as equally responsible for the transgression, never singling out an Eve for blame (Sura 2:36-37 and 7:19-27); in fact, Adam is specifically blamed in Sura 20:121. However, traditionist exegesis indicts Eve as the main transgressor responsible for Adam's fall (Stowasser, 1994:29-30). This interpretation of the narratives of origin

nafs: Corresponding to the Hebrew נֶּפש (nefesh). 
leads to three theological assumptions (Hassan, 2000:3) wherein the status of men are regarded as higher than that of women:

- God's primary creation is man, not woman, since the woman is believed to have been created from man's rib; hence she is derivative and secondary ontologically;

- woman, not man, was the primary agent of what is generally called "The Fall", or man's expulsion from the Garden of Eden; hence all "daughters of Eve" are to be regarded with hatred, suspicion, and contempt;

- woman was created not only from man but also for man, which makes her existence merely instrumental and not fundamental.

The discussion of the qur'anic basis for misogynistic ideas of women does not seem less or more problematic than biblical views on the subject. The verses dealing explicitly with the lower status of women (Sura 2:228, 4:34), when viewed against the whole, are depicted in specific situations and not representative of the qur'anic view of female identity. Women's role and status are far more often expressed as equal to that of men, exemplified in the following verse:

For Muslim men and women, for believing men and women, for devout men and women, for true men and women, for men and women who are patient and constant, for men and women who humble themselves, for men and women who give in charity, for men and women who fast (and deny themselves), for men and women who guard their chastity, and for men and women who engage much in God's praise, - for them has God prepared forgiveness and great reward (Sura 33:35).

However, Muslims believe, together with Jews and Christians, "that Adam was God's primary creation and that Eve was made from Adam's rib"9 (Hassan, 2000:3). This belief is evidenced in the writings of the early and Medieval Islamic interpreters who most probably imported it from biblical traditions (Stowasser, 1994:23). Barbara Stowasser (1994: 28 ) is of the opinion that the scripturalist referent in the hadith "not only fleshes out the story [of human creation] but drastically changes it, especially regarding the woman's role".

Mieke Bal (1985:318) clarifies the subordinate status of women as a misogynistic ideology that is partly based on, and fed into scripturalist assumptions. In summary her analysis entails the reading (by "Paul" in 1 Tim. 2:11-14) of a flawed character image of women in the Fall onto the 
Creation narrative. She (Bal, 1985:319) terms this the "retrospective fallacy" and explicates the method as follows: "It consists of the projection of an accomplished, singular and named character-image on previous textual elements which lead to the construction of that character."

Through this mode of interpretation woman is associated with the binary opposite of righteousness and spirituality - rebelliousness and bodiliness. This is a common feature of many religious, cultural and philosophical traditions.

Hassan (2000:1) argues that although being identified with "body", women have not been seen as "owners" of their bodies. Daniel Boyarin (2000:179) describes the loss of ownership of body for women in Judaism as a result of rabbinic orthodoxy, wherein he suggests that "the struggle for rabbinic authority is ... in part, a struggle for control of women's bodies and sexuality". The struggle is not just for control of the body but also the discourse by the body where Torah is put forward as the sole authority "over any other kind of religious leadership ... including traditional women's power/knowledge" (Boyarin, 2000:180).

Davies (1988:68) views the Islamic process of consolidation of authority in the ulemah (Islamic clergy) correlatively as that the social position and role of the ulemah were elevated and distorted with the elevation of the human interpretation of Islam to divine Law - shari'ah. This process diminished the individual Muslim's self-confidence in articulating her/his own response and a "fixity" of the ulemah:

Instead of applying the lessons of the past to diverse settings, they immersed themselves in a particular historical context, that of the Medina state. The depiction of the Medina state and the life of the Prophet became fixed in time and viewed only as the ancestors had understood it. This vision of the Medina state became the model; the present had always to recast itself in the mould of the past. This conformity was validated in figh. It was no longer a matter of asking new questions of the conceptual base but of using the base of fiqh as an imposition upon contemporary reality, with a precise list of do's and don'ts (Davies, 1988:69).

An historical inquiry shows that hijab became regulatory at the same time as the consolidation of the fuqaha (religio-legal leaders) in the ninth century (third century of the Islamic calendar) (Stowasser, 1994:105; Hitti, 1970:333). 


\section{Hijab: curse or blessing?}

Val Moghadan (1988:223) links an ideology of gender difference with, what she terms "the ideology of domesticity". This implies that the physical, physiological and biological differences between men and "women are translated into universal and immutable differences in their social and intellectual capacities". She (Moghadan, 1988:224) asserts that these ideologies are based on three elements (the three D's): Difference, Danger and Domesticity. The "danger" theme is linked to the perceived danger inherent in the female nature.10

These ideas have been advanced to justify hijab, which in Moghadan's (1988:224) view can be seen as a form of negation of female sexuality, as a critique of women's participation in the public sphere and, in some instances, as reason to reduce women's presence or to ban them altogether from certain arenas. Javed (1994: par. 4) likewise views the concept of hijab as "one of the strategies for coercing women to live an imposed identity rooted in misogynistic assumptions". She cites the same two assumptions about women, i.e. being "dangerous creatures" and further as being "fragile and limited in mental capacity" as reasoning for the mistreatment of women. These assumptions are viewed under the broad umbrella of fitna (social disruption) that calls for the restraint of women in order to protect society (Javed, 1994: par. 9).

The consideration of Islamic and other scripturalist views on the role and status of women leads to the realisation that humankind has appropriated one half of its population with a world defined and an assigned identity and the basis thereof stems from previously instituted/institutionalised and elaborated ideas.

However, the diverse applications and interpretation of women's role in the Islamic community attest to the fact that hijab is not a monolithicly proscribed concept. It is as much a part of the feminist struggle as it is a symbol of defiance of Western cultural domination.11 Stowasser (1994:

10 These ideas are not limited to Islamic society. Hammond (1971:193) cites the Melanesians of New Guinea as prime example of female exclusion from fraternities: "Much is made by the Melanesians of the dangers of the female's supernaturally derived sexuality. Little boys are gravely warned by their elder brothers and fathers to avoid the company of their mothers and sisters and are encouraged to engage in exclusively male activities. Women are barred from many of the ritual activities connected with the men's associations ... just as they are sometimes barred from men's clubs in Europe and the U.S."

11 A striking example is the move in Algeria by the younger generation of women choosing the hijab as a feminist statement in defiance of their parents' disapproval thereof (see Coffman, 1991:23-25). 
127 ) is correct in her analysis of hijab as a "focus of Muslim paradigmatic selfdefinition" but it does not only signify the "traditional institutions governing women's role in Islamic society". Hijab has indeed acquired the status of "cultural symbol" though traditionists and modernists alike defend its application. The central argument of Myfanwy Franks' (2000) article on the headscarf, as representing hijab, argues that it is "of itself, neither liberating nor oppressive, and that the power relations with which it is associated are situated not only in the meaning with which it is invested but also in the circumstances under which it is worn".

Merryl Davies (1988:54) holds the re-appropriation process as a ray of hope for the crisis of religious expression:

Developing other ways of thinking offers the only hopeful prospect for mankind. Instead of believing that humanity is necessarily reduced to the confines of our current predicament, revitalising the concepts and values of other ways of knowing can demonstrate that mankind has the resources and capacity to make sense of its problems and resolve them.

The current conceptual formulation of hijab therefore need not be removed or changed in form, but rather re-appropriated and understood to reflect the significance thereof for the individual believer.

\section{Bibliography}

'ALI, M. 2001. The question of hijab: Suppression or liberation. Islamic Academy for Scientific Research. Chicago : The Institute of Islamic Information and Education. [Available on Internet:] http://www.unn.ac.uk/societies/islamic/women/ hijab.htm [Date of access: 02/20/2001].

'ALI, Y. 1975. Commenting in the Holy Qur'an: Text translation and commentary. London: The Islamic Foundation.

AL-FARUQI, L. 2001. Islamic traditions and the feminist movement: Confrontation or cooperation? [Web:] http://www.beconvinced.com/women/ FEMIN.htm [Date of access: 20 Feb. 2001].

BAL, M. 1985. Sexuality, sin, and sorrow: the emergence of female character. (A reading of Genesis 1-3). (In Suleiman, S.R. The female body in Western culture. Contemporary perspectives. London : Harvard University Press. p. 317338.)

BAM, I. 2001. Imam of Newtown Mosque. Interviewed by Benedict Maage. Radio 702, Wednesday, 10 Oct. 2001, 20:00-21:00.

BOYARIN, D. 2000. On stoves, sex, and slave-girls: Rabbinic orthodoxy and the definition of Jewish identity. Hebrew Studies, XLI:169-188.

BOSS, S. 1998. In Turkey, fashionable devotion. Christian Science Monitor, 90(221):3-13, August. [In EBSCOHost: Academic Search Premier, Full display: http://www-sa.ebsco.com] [Date of access: 3 July 2002].

BROWN, D.W. 1996. Rethinking tradition in modern Islamic thought. Cambridge : University Press. 
COFFMAN, J. 1991. Choosing the veil. Mother Jones, 16(6):23-25. [In EBSCOHost: Academic Search Premier, Full display: http://www-sa.ebsco.com] [Date of access: 3 July 2002].

CRAGG, K. 1973. The mind of the Qur'an: Chapters in reflection. London : Unwin.

DAVIES, M.W. 1988. Knowing one another: Shaping an Islamic anthropology. London : Mansell.

DEN HEYER, C.J. \& SCHELLING, P. 2000. Symbolen en de bijbel: Woorden en hun betekenis. Zoetemeer : Meinema.

DOI, A.I. 1984. Shari'ah: The Islamic law. London : TaHa Publishers.

FRANKS, M. 2000. Crossing the borders of whiteness? White Muslim women who wear the hijab in Britain today. Ethnic and Racial Studies, 23(5):917-1000, September. [In EBSCOHost: Academic Search Premier, Full display: http://www-sa.ebsco.com] [Date of access: 3 July 2002].

GLASSÉ, C. 1989. The Concise Encyclopedia of Islam. New York : Harper \& Row.

HAMMOND, P.B. 1971. An introduction to cultural and social anthropology. New York : Macmillan.

HASSAN, R. 2000. Women in Islam: Body, mind and spirit. Christian social action: The United Methodist Church General Board of Church and Society, June. [Available on Internet:] http://www.umc-gbcs.org/csamay2_jun2000.htm [Date of access 06/18/2001].

HILSUM, L. 1998. Jeans and mascara under the veil. New Statesman, July 10. [Available on Internet:] http://www.britannica.com/magazine/print?content_ id=332966 [Date of access: 06/05/2001].

HITTI, P.K. 1970. History of the Arabs. From the earliest times to the present. 10th ed. Hong Kong: Macmillan.

JAVED, N. 1994. Gender identity and Muslim women: Tool of oppression turned into empowerment. Convergence, 27(2 \& 3):58-68. [In EBSCOHost: Academic Search Premier, Full display: http://www-sa.ebsco.com] [Date of access: 3 July 2002].

JENSEN, J. 1989. Towards contemporary Islamic concepts of person. (In Kippenberg et al., eds. Concepts of person in religion and thought. Berlin : De Gruyter. p.177-216.)

KEDDIE, N.R. 1968. An Islamic response to imperialism: Political and religious writings of Sayyid Jamal ad-Din "al-Afghani". Berkeley : University of California Press.

KIPPENBERG, H.G., KUIPER, Y.B. \& SANDERS, A.F., eds. 1990. Concepts of person in religion and thought. Berlin : De Gruyter.

LE ROUX, C. du P. 1986. Koran en metodologie. Journal for Islamic Studies, (6):3139, Nov.

LOTT, E.J. 1988. Vision, tradition, interpretation: Theology, religion, and the study of religion. Berlin : De Gruyter.

MOGHADAN, V. 1988. Women, work and ideology in Iran. International Journal of Middle East Studies, 20(1):221-243.

PRAETORIUS, I. 1998. Essays in feminist ethics. Morality and the meaning of life, 5. Belgium : Peeters.

PRUSHER, I.R. 2000. Symbol of both oppression and freedom. Christian Science Monitor, 92(183):8, November. [In EBSCOHost: Academic Search Premier, Full display: http://www-sa.ebsco.com] [Date of access: 3 July 2002].

QUR'AN. 1975. The Holy Qur'an: Text, translation and commentary. London : The Islamic Foundation. 
RAFIQUL-HAQQ, M. \& NEWTON, P. 1996. The place of women in pure Islam. Resource Centre for Muslim/Christian Dialog [Available on Internet: http://debate.domini.org/newton/womeng.html] Date of access 26/09/02]

SHAH, S. 2002. Veiled Solidarity. Progressive, 66(1):28-31, January. [In EBSCOHost: Academic Search Premier, Full display: http://www-sa.ebsco.com] [Date of access: 3 July 2002].

STILLE, A. 2002. Radical new views of Islam and the origins of the Koran. The New York Times: March 2. [Available on Internet:] http:///www.nytimes.com/200/03/ 02/arts/02ISLA [Date of access 06/03/2002].

STOWASSER, B. 1994. Women in the Qur'an, traditions, and interpretation. Oxford : Oxford University Press.

STUMPF, S.E. 1983. Philosophy: history and problems. New York : McGraw-Hill.

\section{Key concepts:}

feminism

hijab

identity

Islam

\section{Kernbegrippe:}

feminisme

hidjab

identiteit

Islam 
